\title{
MENENTUKAN KEBUTUHAN KALORI PADA WANITA REMAJA MENGGUNAKAN APLIKASI FUZZY INFERENCY SYSTEM METODE SUGENO
}

\author{
${ }^{1}$ Ayu Chinintya Lestari, ${ }^{2}$ Umi Mukaromatul Masruroh \\ ${ }^{1}$ Institut Agama Islam Negeri Jember, Program Studi Tadris Matematika, (0331) 427005 \\ ${ }^{2}$ Institut Agama Islam Negeri Jember, Program Studi Tadris Matematika, (0331) 427005 \\ e-mail: ayuchinintya98@gmail.com
}

\begin{abstract}
Abstrak
Masa remaja adalah masa pematangan fisik maupun psikologis, sehingga tak sedikit para wanita yang menginginkan tubuh yang sempurna dalam artian tubuh yang ideal. Padahal yang terpenting adalah mengetahui dan menjaga asupan kalori yang dibutuhkan oleh tubuh. Pada penelitian ini, dibangun perangkat lunak yang dapat memudahkan wanita remaja dalam menentukan kebutuhan kalori usia 17-23 tahun. Metode yang digunakan adalah library research dengan analisis fuzzy sugeno untuk menentukan dan menghitung kebutuhan kalori pada wanita remaja dengan mempresentasikan IF-THEN, menginput umur, tinggi badan, dan berat badan sehingga menghasilkan output dalam bentuk konstanta dengan analisis kebenaran dalam standar ideal menentukan kebutuhan kalori wanita remaja sebesar 57\%. Sedangkan analisis kebenaran dalam menentukan kebutuhan kalori wanita remaja menggunakan metode manual, standar idealnya sebesar $23 \%$.
\end{abstract}

Kata Kunci: Fuzzy Sugeno, kebutuhan kalori, wanita remaja

\begin{abstract}
Adolescence is a period of maturation of physical and psychological, so that not a few women who want a perfect body in the sense of the ideal body. But the most important thing is knowing and keeping the intake of calories needed by the body. In this research, built software that can facilitate the adolescent women in determining the caloric needs of the age of 17-23 years. The method used is library research with the analysis of the fuzzy sugeno to determine and calculate calorie needs on teen girls by presenting IF-THEN, input the age, height, and weight so as to produce output in the form of constants with the analysis of truth in the ideal standard to determine calorie needs for teen girls by $57 \%$. While the analysis of the truth in determining the caloric needs of adolescent women using manual methods, standards, ideally by $23 \%$.
\end{abstract}

Keywords: Fuzzy sugeno, caloric needs, teenage women

\section{PENDAHULUAN}

Remaja adalah suatu masa peralihan antara masa anak menjadi masa dewasa yaitu masa dimana seorang mengalami perubahan cara berpikir (psikis) dan juga fisik, salah satu yang menonjol dari masa perubahan ini kesadaran yang mendalam mengenai diri sendiri dimana remaja mulai meyakini kemampuannya, potensi dan keindahan dalam dirinya. Menurut para psikologi, Masa Remaja adalah masa transisi dari awal dewasa, yang dimasuki pada usia sekitar 17-23 tahun. Pada masa remaja bermula pada perubahan fisik yang cepat, pertambahan berat dan tinggi, perubahan bentuk tubuh dan perkembangan karakteristik seksual lainnya. Penampilan diri yang berbeda pada umumnya dapat membuat remaja rendah diri, maka dari itu daya tarik fisik yang dimiliki sangat mempengaruhi dalam penilaian 
tentang ciri kepribadian seseorang remaja.Remaja melakukan diet sebagian besar untuk menjaga penampilan dan tampak menjadi lebih menarik. Kondisi tubuh yang terlalu gemuk melebihi dari standar tinggi badan membuat remaja akanmelakukan segala cara untuk memenuhi keinginannya terutama dengan diet meskipun harus mengabaikan status nutrisi dan kebutuhan gizi dalam tubuh demi mendapatkan proporsi tubuh yang ideal.

Berat badan berlebihan hingga kegemukan jika di lihat dari aspek kesehatan akan beresiko terhadap timbulnya berbagai penyakit selain dari aspek tampilan fisik. Pada usia remaja, perubahan bentuk tubuh merupakan biasa yang di alami, melakukan diet ketat dilakukan untuk mendapatkan bentuk tubuh yang lebih ideal akan membahayakan diri jika tidak memperhatikan nutrisi pada tubuh. Seseorang salah dalam melakukan program diet maka akan mengalami gangguan dalam pemenuhan nutrisi pada tubuh. Diet dalam membatasi untuk mengkonsumsi satu jenis makanan seperti karbohidrat dalam nasi belum tentu menimbulkan dampak perubahan yang serius, tetapi diet yang menganjurkan untuk tidak memakan makanan yang mengandung karbohidrat seperti nasi, mie dan roti sama sekali dan hanya memakan buah dan sayur juga tidak sehat karna keperluan vitamin dan mineral tidak akan mencukupi dengan hanya memakan buah dan sayuran. Kebutuhan karbohidrat akan terpenuhi dengan mengganti dengan karbohidrat jenis lain seperti kentang dan ubi. (Waspadji, 2004: 25).

Ghufron (2010) bependapat bahwa masukan makanan harus selalu cukup untuk mensuplai kebutuhan metabolisme tubuh dan tidak cukup menimbulkan obesitas (kegemukan) karena makanan yag beragam mengandung berbagai protein-kabohidrat dan lemak. Keseimbangan metabolisme tubuh dapat disuplai dengan bahan yang dibutuhkan.

Remaja melakukan program diet sejak remaja dengan usia 18-22 tahun, dua pertiga dari remaja yang melakukan diet dalam menurunkan berat badan mempunyai kemungkinan melakukan pada usia dewasa hingga dua kali lipat. Riyanto (2017) mengemukakan bahwa delapan dari sepuluh remaja yang melakukan diet tanpa memperhatikan keadaan status nutrisi.

Perwira, dkk. (2014) mengemukakan bahwa melakukan diet berarti membatasi dengan cermat pengambilan kalori dalam jenis makanan tertentu.Diet yang tepat membuat berat badan berkurang dan tubuh tetap sehat. Tetapi bila dilakukan secara berlebihan akan membahayakan bagi tubuh, terutama bagi yang dalam masa pertumbuhan karena kurangnya nutrisi dalam jenis dan jumlah yang besar dapat menganggu pertumbuhan dan kesehatan tubuh secara keseluruhan. 
Menurut Perwira (2014) teori dari kalori yang dibutuhkan dalam tubuh dapat ditentukan melalui pemeriksaan laboratorium maupun secara antropometri. Kekurangan kadar hemoglobin atau anemia ditentukan dengan pemeriksaan darah. Allwine dkk. (2019) mengatakan bahwa antropometri merupakan cara penentuan status kalori yang paling mudah dan murah. Indeks Massa Tubuh (IMT) direkomendasikan sebagai indikator yang baik dalam menentukan kebutuhan kalori yang diperlukan oleh tubuh remaja pada umumnya.

Cara pengambilan keputusan perhitungan kalori energi menggunakan konsep sistem pendukung keputusan. Sistem Pendukung keputusan pertama kali diungkapkan oleh Micheal S. Scott Mortonn pada tahun 1970 dengan istilah Management Decision System. Sistem tersebut ditunjukan untuk membantu pengambilan keputusan dengan memanfaatkan data dan model tertentu untuk memecahkan yang tidak terstruktur (Turban, 2005: 57). Model tertentu yang digunakan pada kasus diatas adalah Fuzzy Inference System (FIS) atau Sistem inferensi fuzzy, terdapat beberapa jenis metode FIS yang dikenal yaitu Sugeno dan masih banyak lagi.

Berdasarkan uraian diatas, peneliti tertarik untuk membuat bagaimana Menentukan kebutuhan kalori pada wanita remaja dengan menggunakan aplikasi fuzzy inferency system metode sugeno, ini dilakukan untuk mengetahui jumlah kalori yang dibutuhkan remaja pada umumnya, maka dibuatlah aplikasi untuk menghitung kalori energi, nilai masing-masing kalori energi dan asupan menu makanan yang dbutuhkan. Diharapkan dengan adanya perancangan sistem ini remaja dapat dengan mudah menghitung asupan kalori yang dibutuhkan dalam tubuhnya agar membentuk tubuh yang ideal.

\section{METODE PENELITIAN}

Metode Penelitian ini menggunakan Metode Library Research (penelitian kepustakaan) dengan analisis fuzzy sugeno yaitu penelitian yang dilaksanakan dengan menggunakan literatur (kepustakaan), baik berupa buku, catatan, maupun laporan hasil penelitian dari penelitian terdahulu dan di analisis dengan Metode Inferensi Sistem[Iqbal,(2002)].

Menurut Kusumadewi (2002) metode Fuzzy Inferensi Sistem (Fuzzy inference sistem /FIS) merupakan sistem yang dilakukan melalui penalaran dengan prinsip serupa semisal manusia melakukan penalaran melalui nalurinya(angan). Terdapat beberapa macam teori FIS yang kita kenal diantaranya Mamdani, Sugeno dan Tsukamoto. FIS yang paling mudah dimengerti karena paling sesuai dengan naluri manusia adalah FIS Sugeno, oleh karena itu FIS tersebut bekerja berdasarkan aturan-aturan linguistik dan mempunyai algoritma fuzzy 
yang menyediakan sebuah aproksimasi untuk dimasukan dengan analisa matematik. Disini penulis akan menggunakan metode yang dipakai oleh sugeno.

Metode Sugeno yang digunakan dalam pengembangan perangkat lunak ini ialahfuzzy sugeno, dan menggunakan aturan yangdirepresentasikan dalam bentuk IF-THEN (Jika-maka) dengan output berupa konstanta atau persamaan linier tidak berupa himpunan fuzzy untuk melakukan perhitungan terhadap kebutuhan kalori. Sedangkan input yang digunakan dalam metode fuzzy sugeno ini meliputi umur, tinggi badan, dan berat badan dari tubuh seseorang. Metode ini diperkenalkan oleh Takagi-Sugeno pada tahun 1985.

Sebelum menghitung jumlah kalori melalui IMT, yang dibutuhkan remaja terlebih dahulu ialah kita harus mengetahui berapa berat badan dan tinggi badan seseorang remaja tersebut, cara menghitung berat badan ideal dengan menggunakan perhitungan manual rumus BMI:

$$
\begin{aligned}
& \operatorname{IMT}(B M I)=\text { Berat badan }(\mathrm{Kg}) X \text { Tinggi Badan }(\mathrm{m}) \\
& \text { Tinggi Badan (m) }
\end{aligned}
$$

\begin{tabular}{|l|l|l|}
\hline No & IMT & Klasifikasi \\
\hline 1. & $<1000 \mathrm{kkal}$ & Kurus \\
\hline 2. & $1000 \mathrm{kkal}>$ Kalori $>1500 \mathrm{kkal}$ & Normal \\
\hline 3. & $>1500 \mathrm{kkal}$ & Gemuk \\
\hline
\end{tabular}

Menurut Kusmadewi dan Purnomo(2010) Model fuzzy Sugeno diantaranya :

1. Model Fuzzy Sugeno Orde-0

Bentuk model fuzzy orde nol secaara umum yaitu:

IF $\left(x_{1} \text { is } A_{1}\right)^{0}\left(x_{3} \text { is } A_{3}\right)^{0}\left(x_{3} \text { is } A_{3}\right)^{0} \ldots\left(x_{n}\right.$ is $\left.A_{n}\right)$

THEN $z=k$

Dengan Ai merupakan himpunan fuzzy ke-i sebagai Anteseden. ${ }^{0}$ sebagai operator fuzzy (AND atau OR) serta k sebagai konstanta (tegas) sebagai konsekuen.

2. Model Fuzzy Sugeno Orde-1

Bentuk model fuzzy orde satu secara umum yaitu:

IF $\left(x_{1} \text { is } A_{1}\right)^{0} \ldots{ }^{0}\left(x_{n}\right.$ is $\left.A n\right)$

THEN $z=p_{1} * x_{1}+\ldots .+p_{n} * x_{n}+q$

Dengan Ai adalah himpunan fuzzy ke-i sebagai Anteseden. ${ }^{0}$ sebagai operator fuzzy (AND atau OR), $p_{1}$ adalah suatu konstanta (tegas) ke-i dan q merupakan konstanta dalam konsekuen. 
Dalam inferensinya, metode sugeno menggunakan tahapan berikut:

1. Fuzzifikasi

2. Pembentukan basis pengetahuan fuzzy (Rule dalam bentuk IF ... THEN)

3. Mesin inferensi

Menggunakan fungsi implikasi MIN untuk mendapatkan nilai a-predikat tiap tiap rule $\left(a_{1}, a_{2}, a_{3}, \ldots a_{n}\right)$

Kemudian masing-masing nila a-predikat ini digunakan untuk menghitung

keluaran hasil inferensi secara tegas (crisp) masing-masing rule $\left(z_{1}, z_{2}, z_{3}, \ldots z_{n}\right)$.

4. Defuzzifikasi menggunakam metode rata-rata (Avarege)

$$
\begin{aligned}
& \mathrm{Z}=\underline{\sum a i z i} \\
& \sum a i
\end{aligned}
$$

Desain penelitian yang digunakan dalam penelitian ini adalah sebagai berikut :

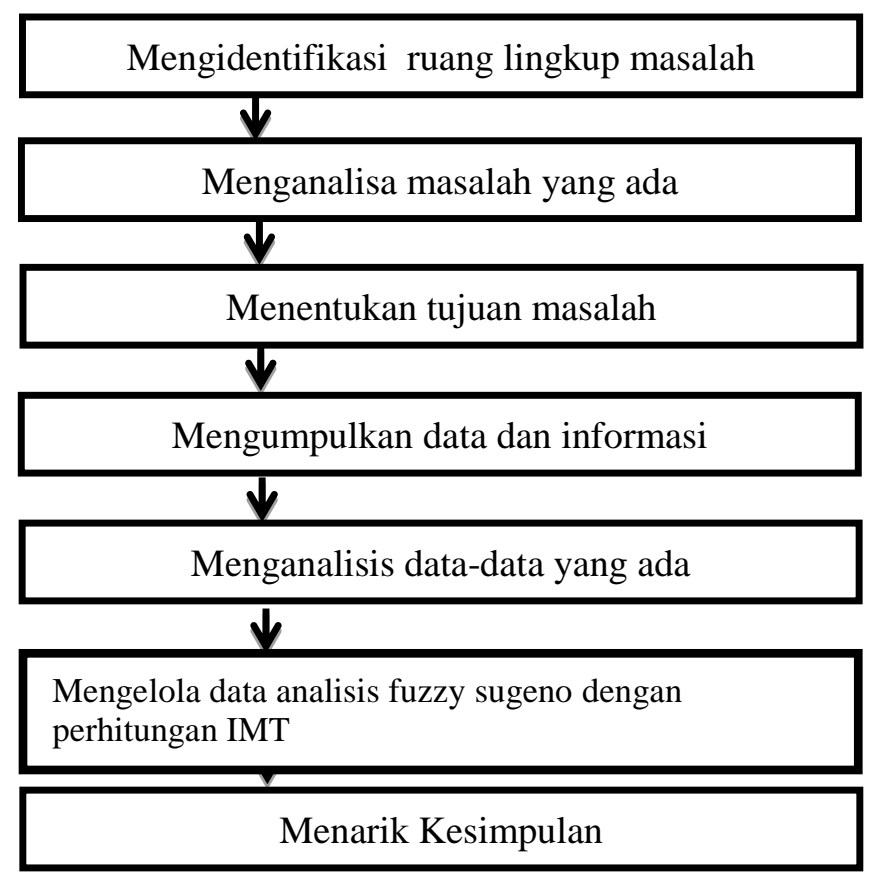

Gambar 1. Desain Penelitian

Desain penelitian yang digunakan dalam penelitian ini adalah sebagai berikut :

1. Mengidentifikasi ruang lingkup masalah : Penelitian dimulai dengan mengidentifikasi masalah yang ada pada objek penelitian yaitu penentuan kios terbaik di kepri mall. 
2. Menganalisis masalah : setelah proses mengidentifikasi masalah dilakukan, selanjutnya adalah menganalisis masalah yang ada, membatasi masalah yang akan dinahas pada penelitian.

3. Menentukan tujuan penelitian : setelah dilakukan analisa masalah yang ada, seanjutnya ditentukan tujuan akhir dari penelitian ini, agar penelitian ini dapat bermanfaat.

4. Mengumpulkan data dan informasi : Untuk mendapatkan data dan informasi yang berguna untuk pengelolaan data dan informasi dengan data kepustakaan.

5. Menganalisis data-data yang ada : Setelah dilakukan proses pengumpulan data informasi untuk penelitian ini, mulai dianalisis variabel dan indikator yang nantinya akan di olah dengan analisis metode fuzzy Sugenodengan Perhitungan IMT (BMI) yaitu Berat badan dibagi tinggi badan dikalikan tinggi badan

6. Menggolah data dengan metode fuzzy sugeno : pada langkah ini seluruh data berupa variabel dan indikator yang ada diolah dengan menggunakan metode fuzzy segeno

7. Menarik kesimpulan : Hasil dari pengujian yang dilakukan pada penelitian ini dengan menggunakan Perhitungan IMT (BMI) yaitu Berat badan dibagi tinggi badan dikalikan tinggi badan, maka hasil tersebut dapat dijadikan perhitungan dalam menentukan kebutuhan kalori yang dibutuhkan dalam tubuh.

\section{HASIL DAN PEMBAHASAN}

Pengujian perangkat lunak diperlukan untuk menentukan kebutuhan kalori wanita remaja dengan membandingkan hasil analisis fuzzy sugeno dengan metode manual terhadap 30 wanita remaja yang berusia sekitar 17-23 tahun serta disesuaikan dengan batas atas dan batas bawah standar ideal. Selisih perbandingan hasil analisis fuzzy sugeno dan metode manual harus memenuhi batas atas dan batas bawah standar ideal menggunakan perhitungan statistika inferensial dengan prosentase kepercayaan yakni 95\% agar pengujian yang dilakukan dapat bernilai benar dan valid. Adapun 30 data wanita remaja yang telah diuji coba adalah sebagai berikut : 


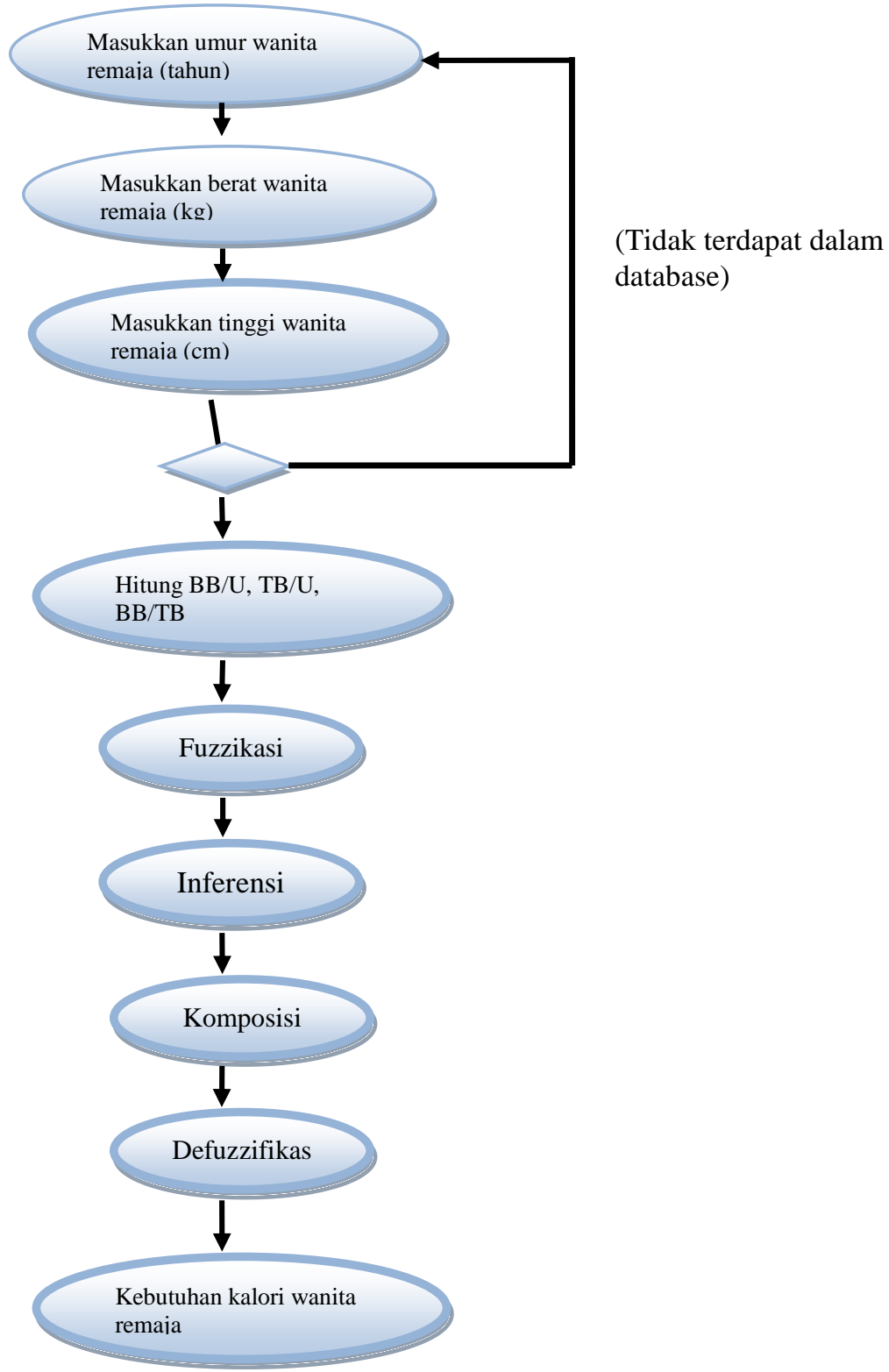

Gambar 1. Activity Diagram Hitung Kebutuhan Kalori Wanita Remaja

Tabel 1. Batas atas dan batas bawah dalam uji coba kebutuhan kalori

\begin{tabular}{|c|c|c|}
\hline Selisih & $\begin{array}{c}\text { Metode Manual dan Standar } \\
\text { Ideal }\end{array}$ & Metode Fuzzy Sugeno dan Standar Ideal \\
\hline Batas atas & -13253 & 9.74 \\
\hline Batas bawah & 258.99 & -46.54 \\
\hline
\end{tabular}

Perhitungan kalori menurut Suryo (2017), yaitu:

1. Perhitungan analisis kebenaran fuzzy sugeno terhadap standar ideal, yakni:

Prosentase kebutuhan kalori = (nilai analisis kebenaran/jumlah banyaknya data) x $100 \%$ 


$$
\begin{aligned}
& =(17 / 30) \times 100 \% \\
& =57 \%
\end{aligned}
$$

2. Perhitungan analisis kebenaran metode manual terhadap standar ideal, yakni:

Prosentase kebutuhan energi = nilai analisis kebenaran/jumlah banyaknya data) $\mathrm{x}$ $100 \%$

$$
\begin{aligned}
& =(7 / 30) \times 100 \% \\
& =23 \%
\end{aligned}
$$

Hasil perhitungan kebutuhan kalori berdasarkan fuzzy sugeno sesuai standar ideal yaitu sebesar 57\% sedangkan hasil perhitungan kebutuhan kalori berdasarkan metode manual sesuai standar ideal sebesar 23\%. Hal ini dapat berbeda karena indikator pada fuzzy sugeno yang disesuaikan standar ideal adalah berat badan menurut umur, tinggi badan menurut umur, dan berat badan menurut tinggi badan sehingga menghasilkan kebutuhan kalori berpedoman pada berat badan dan tinggi badan wanita remaja. Sedangkan indikator pada metode manual yang disesuaikan dengan standar ideal yaitu hanya berat badan menurut umur, sehingga kebutuhan

\begin{tabular}{|c|c|c|c|c|c|c|c|}
\hline \multirow[t]{2}{*}{$\mathrm{NO}$} & \multicolumn{3}{|c|}{ Kebutuhan Kalori (Kkal) } & \multirow{2}{*}{$\begin{array}{c}\text { Selisih } \\
\text { Metode } \\
\text { Manual } \\
\text { dengan } \\
\text { Standar } \\
\text { Ideal (X) }\end{array}$} & \multirow{2}{*}{$\begin{array}{c}\text { Selisih } \\
\text { Metode Fuzzy } \\
\text { Sugeno } \\
\text { dengan } \\
\text { Standar Ideal } \\
\text { (Y) }\end{array}$} & \multicolumn{2}{|c|}{$\begin{array}{c}\text { Analisis Kebenaran } \\
\text { terhadap Standar Ideal } \\
\text { berdasarkan Batas Atas } \\
\text { dan Batas Bawah }\end{array}$} \\
\hline & $\begin{array}{c}\text { Standar } \\
\text { Ideal }\end{array}$ & $\begin{array}{l}\text { Metode } \\
\text { Manual }\end{array}$ & $\begin{array}{l}\text { Metode } \\
\text { Fuzzy } \\
\text { Sugeno }\end{array}$ & & & $\begin{array}{c}-258.99<X<- \\
132.53\end{array}$ & $\begin{array}{l}- \\
46.54< \\
Y<9.74\end{array}$ \\
\hline 1. & 1500 & 1190 & 1418.32 & -280 & -31.68 & Benar & Benar \\
\hline 2. & 1480 & 1410 & 1594.69 & -36 & -53.35 & Salah & Salah \\
\hline 3. & 1460 & 1400 & 1443.30 & 54 & -6.43 & Salah & Benar \\
\hline 4. & 1440 & 1370 & 1530.00 & -351 & 6.57 & Salah & Benar \\
\hline 5. & 1510 & 1530 & 1612.57 & -18 & -56.9 & Benar & Benar \\
\hline 6. & 1490 & 1700 & 1650.65 & 45 & 43.65 & Salah & Benar \\
\hline 7. & 1480 & 1400 & 1551.69 & 162 & -35.81 & Salah & Benar \\
\hline 8. & 1620 & 1370 & 1616.08 & 72 & -36.65 & Salah & Benar \\
\hline 9. & 1570 & 1390 & 1603.35 & -216 & -3.26 & Salah & Salah \\
\hline 10. & 1510 & 1630 & 1453.03 & 162 & -24.03 & Benar & Benar \\
\hline 11. & 1528 & 1412 & 1510.15 & -430 & -86.31 & Salah & Benar \\
\hline 12. & 1456 & 1520 & 1536.1 & -320 & -28.48 & Salah & Benar \\
\hline 13. & 1575 & 1415 & 1603.35 & 300 & -41.68 & Salah & Salah \\
\hline 14. & 1546 & 1348 & 1567.12 & -270 & 33.14 & Salah & Benar \\
\hline 15. & 1495 & 1415 & 1404.37 & -216 & 2.45 & Benar & Benar \\
\hline 16. & 1573 & 1160 & 1365.00 & 45 & 6.78 & Salah & Benar \\
\hline 17. & 1490 & 1270 & 1498.13 & 9 & 136.65 & Salah & Salah \\
\hline 18. & 1440 & 1430 & 1531.55 & -280 & 6.57 & Salah & Benar \\
\hline
\end{tabular}
kalori yang dihasilkan berpedoman pada beran badan wanita remaja. Berdasarkan data Depkes RI (2018), didapatkan hasil sebagai berikut:

Tabel 2. Percobaan terhadap kebutuhan kalori untuk 30 data wanita remaja 


\begin{tabular}{|r|l|l|l|l|l|l|l|}
\hline 19. & 1550 & 1390 & 1612.00 & -200 & 43.76 & Benar & Benar \\
\hline 20. & 1521 & 1425 & 1415.18 & -390 & -48.92 & Salah & Benar \\
\hline 21. & 1540 & 1280 & 1477.75 & -340 & -55.9 & Salah & Benar \\
\hline 22. & 1490 & 1352 & 1432.75 & -410 & -52.88 & Salah & Salah \\
\hline 23. & 1449 & 1570 & 1481.59 & -207 & 71.30 & Benar & Benar \\
\hline 24. & 1470 & 1610 & 1360.47 & -360 & 12.65 & Salah & Benar \\
\hline 25. & 1480 & 1477 & 1427.87 & -378 & 34.9 & Salah & Salah \\
\hline 26. & 1530 & 1558 & 1365.09 & -297 & -7.16 & Salah & Benar \\
\hline 27. & 1570 & 1500 & 1629.19 & -198 & 1.43 & Salah & Benar \\
\hline 28. & 1530 & 1252 & 1390.00 & -390 & -3.22 & Salah & Benar \\
\hline 29. & 2657 & 1340 & 1531.55 & -378 & -0.69 & Benar & Salah \\
\hline 30. & 1665 & 1104 & 1498.13 & -220 & 5.52 & Salah & Benar \\
\hline
\end{tabular}

\section{SIMPULAN DAN SARAN}

Pada penelitian yang dilakukan terhadap 30 wanita remaja berusia sekitar 17-23 tahun, didapatkan hasil perhitungan dari analisis kebenaran fuzzy sugeno sesuai standar ideal sebesar 57\%. Hal ini dapat dikatakan mendekati kebutuhan tubuh ideal. Sedangkan dalam menentukan kebutuhan kalori berdasarkan analisis kebenaran metode manual sesuai standar ideal sebesar 23\% . Jadi dapat disimpulkan bahwa analisis fuzzy sugeno jauh lebih mendekati kebutuhan tubuh ideal jika dibandingkan dengan metode manual. Oleh sebab itu analisis fuzzy sugeno dapat dijadikan pilihan lain atau alternatif dalam menentukan kebutuhan kalori sesuai dengan kebutuhan tubuh ideal wanita remaja.

\section{DAFTAR PUSTAKA}

Books:

Depkes. RI. (2018). Analisis Situasi Gizi dan Kesehatan Masyarakat, Jakarta.

Ghufron. (2010). Teori-teori Perkembangan. Bandung: Refika Aditama

Kusumadewi, Sri. (2002). Analisis Desain Sistem Fuzzy Menggunakan Tool Box Matlab. Yogyakarta: Graha Ilmu

Kusumadewi, Sri dan Purnomo (2010). Aplikasi Logika Fuzzy. Y Yogyakarta: Graham Ilmu M. Iqbal, Hasan, Pokok-pokok Materi Metodologi Penelitian dan Aplikasinya, Ghalia Indonesia, Bogor, 2002.

Perwiraaa, Rifki Indra. 2014. "Purwarupa Sistem Pakar Untuk Menentukan Jumlah Kalori Diet Bagi Penderita Diabetes Mellitus”. Telematika.

Turban, E, 2005,Decision Support System and Intelligent Systems Edisi Bahasa Indonesia Jilid 1, Andi, Yogyakarta. 
Waspadji , Sarwono. (2004). Cara Mudah Mengatur Makanan Sehari-Hari Seimbang

Dan Sesuai Kebutuhan Gizi. Jakarta : Balai Penerbit FKUI.

\section{Journal:}

Allwine dkk. (2019). Sistem Pakar Mendeteksi Tingkat Resiko Penyakit melalui Gejala dan Pola Hidup menggunakan Metode Fuzzy Mamdani. Jurnal Mantik Penusa, 3 (3).

Dwi Suryo . (2017). Aplikasi Perhitungan Kalori Energi Menggunakan Metode Fuzzy

Sugeno Berbasis Android. Jakarta: Jurnal Profesional, 4.

Rosida Wachdani dkk. (2013). Aplikasi Fuzzy Inference System (FIS) Metode Sugeno dalam Menentukan Kebutuhan Energi dan Protein pada Balita. Jurnal Netro Professional, 1 (2).

\section{Theses, Dissertation:}

M. Arif Riyanto dkk. (2017). Sistem Pendukung Keputusan Pola Olahraga berdasarkan Hasil yang Ingin dicapai menggunakan Fuzzy Database Model. Prosiding Seminar Ilmu Komputer dan Teknologi Informasi, 2 (1). 